\title{
PROGRAM PENDAMPINGAN CALON TENAGA MEDIS PRIMER DALAM PRAKTEK KOMUNIKASI KESEHATAN SEBAGAI ALTERNATIF PENGOBATAN NON MEDIS
}

\author{
Suci Shinta Lestari ${ }^{1, *}$, Hayatullah Kurniadi ${ }^{1}$, Suzy Yolanda Gussman ${ }^{1}$ \\ ${ }^{1}$ Program Studi Ilmu Komunikasi, Fakultas Ilmu Sosial dan Ilmu Politik, Universitas \\ Abdurrab \\ *Email: suci.shinta@univrab.ac.id
}

\begin{abstract}
ABSTRAK
Dalam kegiatan pengabdian ini kami telah memfasilitasi calon tenaga medis primer dalam mengimplementasikan komunikasi kesehatan yakni mahasiswa kedokteran, mahasiswa keperawatan, kebidanan, dan mahasiswa analis makanan dan farmasi. Kami memberikan konsultasi, pemodelan, dan pembinaan pribadi dan spesifik untuk isu-isu spesifik dalam pelaksanaan Komunikasi Kesehatan dan memberikan solusi kontekstual untuk memecahkan masalah yang dihadapi saat menerapkan Komunikasi Kesehatan, meningkatkan kualitas perawatan kesehatan yang prima melalui penerapan komunikasi kesehatan secara inovatif dan kontekstual berkelanjutan. Tiga pakar komunikasi dan satu pakar konseling secara bergiliran memberikan materi selama kegiatan pengabdian. Pada kesempatan itu, para peserta juga langsung mempraktikkan konsep yang telah didapat melalui kegiatan simulasi. Beberapa orang sengaja dipilih untuk melakukan adegan tertentu dengan setting rumah sakit. Peserta diwajibkan untuk menangani setiap orang yang bertindak sebagai pasien melalui keterampilan komunikasi kesehatan yang telah ditingkatkan.
\end{abstract}

Kata kunci: Program Mentoring, Komunikasi Kesehatan

\section{ABSTRACT}

In this mentoring activity we have been facilitate primary medical personnel candidate in implernentation of Health communication such as medical student, nursing student, obstetrics, and pharmaceutical \& food analysts student. Provide consultation, modeling, and personal and specific coaching for specific issues in the implementation of Health Communication Help provide contextual solutions to solve problems faced when implementing Health Communication Establish a culture of excellent health care quality through the application of health communication in an innovative, contextual, and sustainable manner. Three communications experts and one counseling expert in turn providing material during the service. On that occasion, the participants also directly practiced the concepts that have been obtained through simulation activities. some people are deliberately chosen to do certain scenes with hospital setting. participants are required to deal with each person who acts as a patient through upgraded health communication skills.

Key words : Mentoring Program, Health Communication 


\section{PENDAHULUAN}

Dimasa depan pelayanan kesehatan akan semakin berat, mengingat situasi global dan kondisi pembangunan kesehatan yang semakin memerlukan teknologi tinggi, terutama setelah terbitnya UU NO 44 tahun 2009 tentang RS, UU NO 36 tahun 2009 tentang kesehatan, implementasi UU BPJS kesehatan sebagai tindak lanjut dari UU NO 40 tahun 2004 SJSN (Sistem Jaminan Sosial Nasional), Peran tenaga medis primer akan semakin strategis dan penting mengingat fungsinya sebagai garda terdepan sistem rujukan medis dalam pelaksanaan sistem kesehatan Nasional.

Riau merupakan daerah yang memiliki kondisi geografis yang menguntungkan sekaligus menjadi tantangan bagi pembangunan kesehatan, mengingat masih adanya disparitas antar wilayah dan disparitas sosial ekonomi yang ditengarai menjadi hambatan bagi pelaksanaan kesehatan yang merata dan bermutu. Profesi tenaga medis bukanlah status strata sosial, bukan pula status pencapaian kemapanan ekonomi. Perlu kita ingat tenaga medis primer bukanlah bagian eksklusif di dalam masyarakat, yang dapat menjadi agen ketimpangan dalam masyarakat. Bukan hanya di dalam masyarakat, tenaga medis primer pun seharusnya tidak menjadi agen ketimpangan dalam institusi kecil tempat kerjanya seperti rumah sakit, puskesmas, dan sebagainya.

Tenaga medis primer mempunyai kompetensi dan keunggulan pada pelayanan primer sekaligus menjadi garda terdepan membangun sistem pelayanan kesehatan di Riau. Terutama pada aspek preventif dan promotif, dengan profesialisme dan kompetensi Ilmu komunikasi kesehatan yang terus ditingkatkan, agar terwujud sistem rujukan medik yang berkualitas, yang pada gilirannya nanti masyarakat akan memperoleh manfaat dari Komunikasi pelayanan kesehatan yang bermutu tersebut.

Dengan pola hubungan tenaga medis primer dan pasien yang telah mengalami pergeseran dari zaman ke zaman. Terdapat suatu pergeseran paradigma, dimana tenaga medis bukan lagi dianggap sebagai dewa atau orang suci tetapi telah menjadi figur manusia biasa. Hubungan antara tenaga medis dan pasien yang dulunya menganut pola paternalistik berubah menjadi hubungan yang bersifat kontraktual. Kondisi dan situasi saat ini telah menempatkan tenaga medis dalam peran sebagai pelaku ekonomi yakni sebagai penyedia layanan jasa. Sehingga, apabila jasa yang diberikan tidak memuaskan pasien, maka pasien pun berhak untuk menyampaikan keluhan bahkan sampai pada tuntutan hukum ke pengadilan.

Banyaknya bermunculan pelayanan kesehatan non medis yang tidak diketahui evidence based-nya, yang ternyata diserbu oleh masyarakat awam misalnya pengobatan alternatif dukun cilik Ponari di Jombang dan sebagainya adalah indikasi adanya fenomena menurunnya minat orang sakit untuk memeriksakan dirinya ke dokter. Fenomena tersebut mungkin dipengaruhi oleh tingginya biaya kesehatan maupun berkurangnya kepercayaan masyarakat pada pelayanan medis.

Komunikasi berasal dari kata "communicare" yang berarti berpartisipasi atau memberitahukan dan "communis" yang berarti milik bersama. Komunikasi mengandung beberapa pengertian komunikasi, yaitu: (1) Pertukaran pikiran atau keterangan dalam rangka menciptakan rasa saling mengerti serta saling percaya demi terwujudnya hubungan yang baik antara seseorang dengan orang lainnya; (2) Pertukaran fakta, gagasan, opini atau emosi antar dua orang atau lebih, dan (3) Suatu hubungan yang dilakukan melalui surat, kata-kata, simbol atau pesan yang bertujuan agar tiap manusia yang terlibat dalam proses dapat saling tukar menukar arti dan pengertian terhadap sesuatu (Liliweri A, 2008).

Pada prinsipnya, komunikasi bertujuan untuk menimbulkan saling pengertian, bukan persetujuan. Dalam suatu komunikasi seseorang bisa saja tidak menyetujui pesan yang disampaikan, tetapi apabila orang tersebut memahami pesan tersebut maka dikatakan 
komunikasi telah berjalan baik. Terdapat lima unsur yang berperan dalam komunikasi, yakni sumber, pesan, media, sasaran, umpan balik dan akibat. Sumber (pengiriman berita atau komunikator) adalah tempat asalnya pesan. Pesan atau berita adalah rangsangan atau stimulasi yang disampaikan sumber pada sasaran. Pesan tersebut pada dasarnya adalah hasil pemikiran atau pendapat sumber yang ingin disampaikan pada orang lain. Penyampaian pesan dapat dilakukan dalam beberapa bentuk, yakni kata-kata (simbol berupa kata-kata) atau dalam bentuk bukan kata-kata (simbol berupa gerakan tubuh, gerakan tangan, ekspresi wajah dan gambar). Isi simbolik dari pesan disebut informasi, dan jika sifatnya sebagai sesuatu yang baru disebut inovasi. Media (alat pengirim pesan atau saluran pesan) adalah alat atau saluran yang dipilih oleh sumber untuk menyampaikan pesan pada sasaran.

Hal-hal yang telah dipaparkan diatas menunjukkan bahwa ada sederetan tugas berat bagi profesi tenaga medis primer lebih khusus para dokter untuk mewujudkan optimalisasi perannya dengan sikap profesionalisme menghadapi pasien. Hal inilah yang menuntut tanggung jawab praktisi komunikasi dalam mendampingi tenaga medis primer memberdayakan dirinya ditempatnya bertugas (baik di rumah sakit maupun di puskesmas) dalam penerapan komunikasi kesehatan sebagai praktek kesehatan non medis guna memotivasi pasien untuk sembuh.

\section{METODE}

Kegiatan pengabdian masyarakat ini diadakan di Kampus Universitas Abdurrab Pekanbaru. Dengan rincian sebagai berikut :

Hari/Tanggal: Jumat, 12 Mei 2017

Jam : $08.00-12.00 \mathrm{WIB}$

Ruang : : Ruang serbaguna Prodi Ilmu Komunikasi FISIPOL - Gedung Tarikh Bin Ziyad Universitas Abdurrab Pekanbaru

Kegiatan pengabdian kepada masyarakat ini dilakukan dengan metode ceramah tatap muka dari narasumber yang berjumlah 4 orang. Rinciannya terdapat pada tabel 2.1. berikut ini:

Tabel 2.1. Nama narasumber dan materi

\begin{tabular}{|c|c|c|c|c|c|}
\hline No & Jam & $\begin{array}{c}\text { Program } \\
\text { Pendampingan }\end{array}$ & Materi & Narasumber & Keterangan \\
\hline 1 & $\begin{array}{l}8.30- \\
09.10\end{array}$ & $\begin{array}{l}\text { Councelling } \\
\text { Treatment }\end{array}$ & $\begin{array}{l}\text { Urgensi } \\
\text { memaha } \\
\text { mi } \\
\text { kesehata } \\
\text { n jiwa }\end{array}$ & $\begin{array}{l}\text { M. Fahli } \\
\text { Zatrahadi,S.Sos.,M.P } \\
\text { d.I }\end{array}$ & Hypnotherapyst \\
\hline 2 & $\begin{array}{l}9.20- \\
10.00\end{array}$ & $\begin{array}{l}\text { Kedalaman } \\
\text { Analisis \& } \\
\text { Modelizing }\end{array}$ & $\begin{array}{l}\text { Komunik } \\
\text { asi } \\
\text { Kesehata } \\
\mathrm{n} \\
\text { (Dokter } \\
\text { Pasien) } \\
\text { sebagai } \\
\text { pengobat } \\
\text { an } \\
\text { pentingn } \\
\text { on medis }\end{array}$ & $\begin{array}{l}\text { Hayatullah } \\
\text { Kurniadi,S.I.Kom., } \\
\text { M.A }\end{array}$ & $\begin{array}{l}\text { Presentasi hasil } \\
\text { penelitian \& } \\
\text { pengidentifikasia } \\
\text { n model } \\
\text { penerapan } \\
\text { komunikasi } \\
\text { kesehatan yang } \\
\text { dapat ditiru oleh } \\
\text { peserta }\end{array}$ \\
\hline
\end{tabular}




\begin{tabular}{|c|c|c|c|c|c|}
\hline 3 & $\begin{array}{l}10.10- \\
10.50\end{array}$ & $\begin{array}{l}\text { Pelatihan } \\
\text { personal dan } \\
\text { spesifik }\end{array}$ & $\begin{array}{l}\text { Profesioa } \\
1 \text { Ethic \& } \\
\text { kecakapa } \\
\mathrm{n} \\
\text { interpers } \\
\text { onal }\end{array}$ & $\begin{array}{l}\text { Suzy Yolanda } \\
\text { Gussman,S.Sos.,M. } \\
\text { A }\end{array}$ & $\begin{array}{l}\text { Coaching \& } \\
\text { solusi kontektual } \\
\text { penyelesaian } \\
\text { masalah dalam } \\
\text { implementasi } \\
\text { komunikasi } \\
\text { kesehatan }\end{array}$ \\
\hline 4 & $\begin{array}{l}11.00- \\
11.40\end{array}$ & $\begin{array}{l}\text { Praktek } \\
\text { Penerapan \& } \\
\text { Evaluasi }\end{array}$ & $\begin{array}{l}\text { Serangka } \\
\text { ian tes }\end{array}$ & $\begin{array}{l}\text { Suci Shinta } \\
\text { Lestari,S.Sos.,M.I.K }\end{array}$ & $\begin{array}{l}\text { Peserta } \\
\text { mengkonstrusi } \\
\text { pengetahuan } \\
\text { secara mandiri } \\
\text { (self directed) }\end{array}$ \\
\hline
\end{tabular}

Selain menyampaikan materi mengenai komunikasi kesehatan, dosen yang terlibat dalam kegiatan ini juga mengamati variabel yang memiliki keterkaitan, yakni komunikasi kesehatan yang dilakukan oleh calon tenaga medis primer dalam memberikan pelayanan kesehatan kepada pasien yang diinterpretasikan dalam serangkaian tes. Hasil tersebut adalah data yang paling mendasar dalam kegiatan ini.

Setelah data diperoleh maka selanjutnya akan dianalis dengan mengorganisasikan data, menjabarkannya ke dalam unit-unit, menyusun ke dalam pola, memilih mana yang penting dan mana yang akan dikaji dalam program pendampingan lanjutan. Sementara itu metode yang terapkan dalam kegiatan pengabdian ini adalah sebagai berikut :

a) Memfasilitasi implernentasi komunikasi kesehatan kepada calon tenaga medis primer

b) Memberikan bantuan konsultasi, pemodelan (modelizing), pelatihan personal dan spesifik (coaching) untuk hal-hal spesifik dalam implementasi Komunikasi Kesehatan

c) Memberikan solusi kontekstual dalam menyelesaikan permasalahan yang dihadapi saat implementasi Komunikasi Kesehatan

d) Membangun budaya mutu pelayanan kesehatan yang prima melalui penerapan komunikasi kesehatan secara inovatif, kontekstual, dan berkelanjutan.

\section{HASIL DAN PEMBAHASAN}

Dalam kegiatan pengabdian ini kami telah memfasilitasi calon tenaga medis primer dalam mengimplementasikan komunikasi kesehatan yakni mahasiswa kedokteran, mahasiswa keperawatan, kebidanan, dan mahasiswa analis makanan dan farmasi. Pelaksanaan kegiatan pengabdian masyarakat ini mendapatkan perhatian yang baik dari seluruh peserta yang hadir.

Materi pada kegiatan pendampingan ini memudahkan peserta berpikir secara konstruktif tentang pentingnya komunikasi kesehatan, dimana selain dapat meningkatkan pelayanan kesehatan di Riau dan Indonesia pada umumnya, maka dapat juga digunakan dan dimanfaatkan sebagai pengobatan non medis. Untuk lebih jelas, berikut kami sertakan foto-foto kegiatan lengkap dengan penjelasan tiap-tiap bagiannya. 


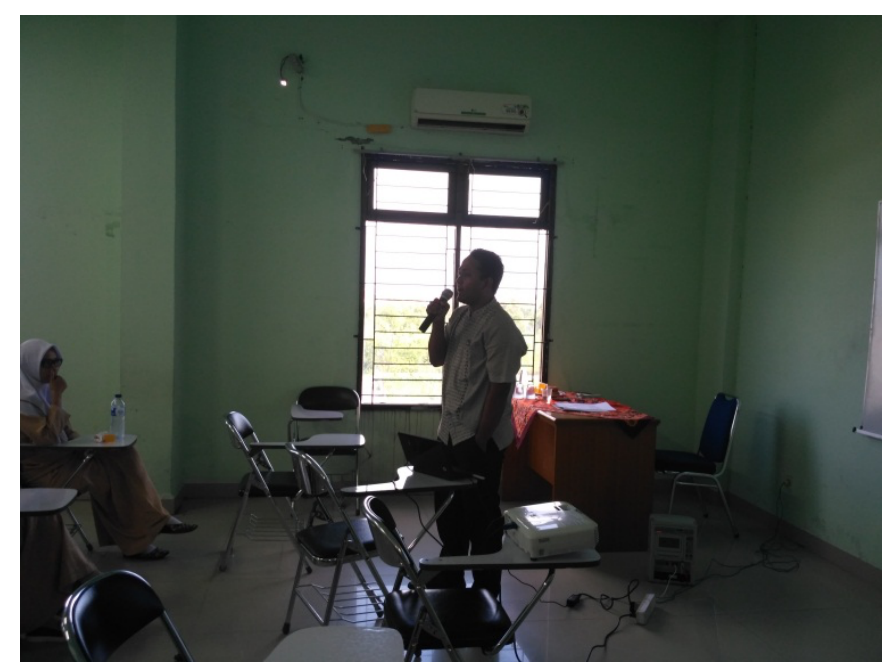

Gambar 1: Hayatullah Kurniadi saat Presentasi hasil penelitian \& pengidentifikasian model penerapan komunikasi kesehatan

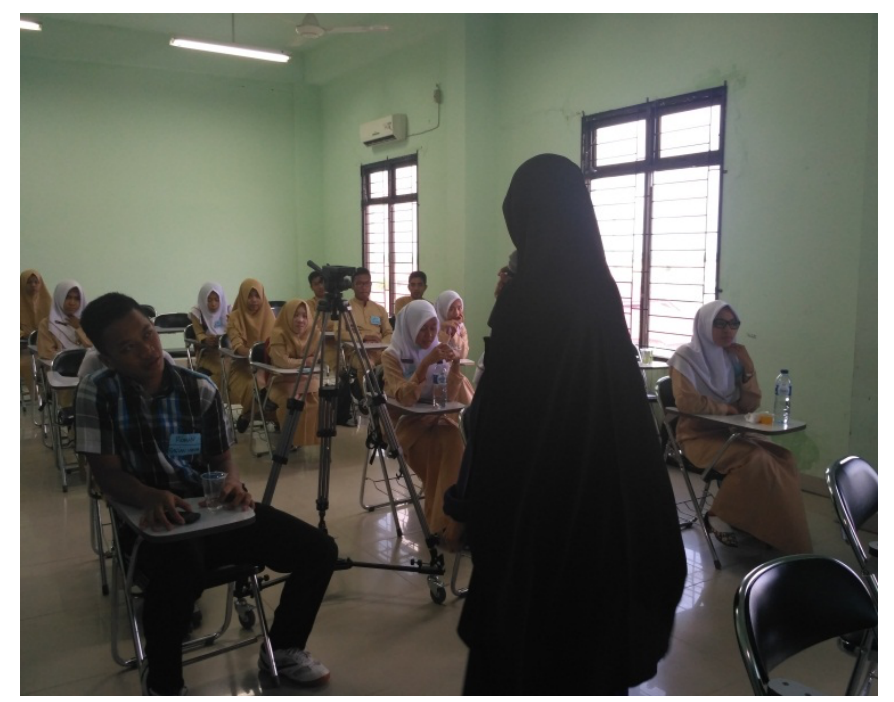

Gambar 2: Suzy Yolanda Gussman Coaching \& solusi kontektual penyelesaian masalah dalam implementasi komunikasi kesehatan

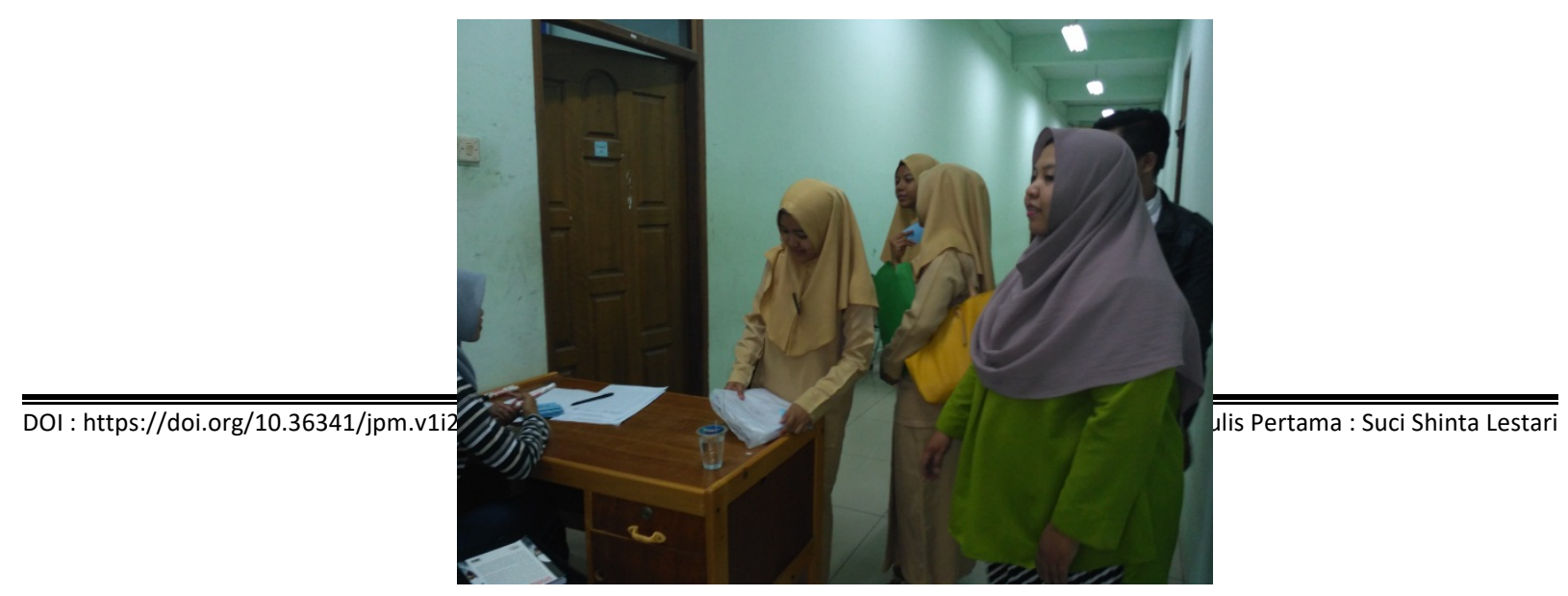


Gambar 3: Suci Shinta Lestari ketika memberikan instruksi terkait Praktek Penerapan \& Evaluasi kegiatan pendampingan

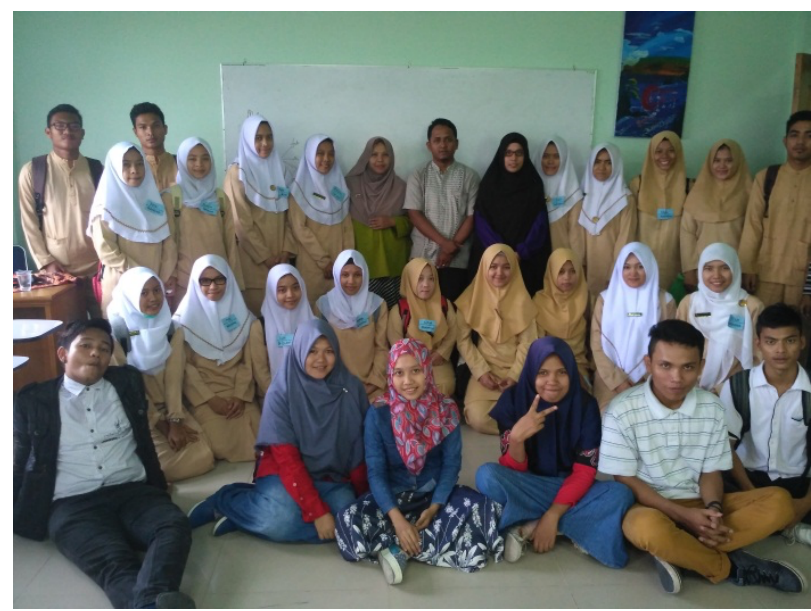

Gambar 4: Foto bersama Narasumber dan peserta

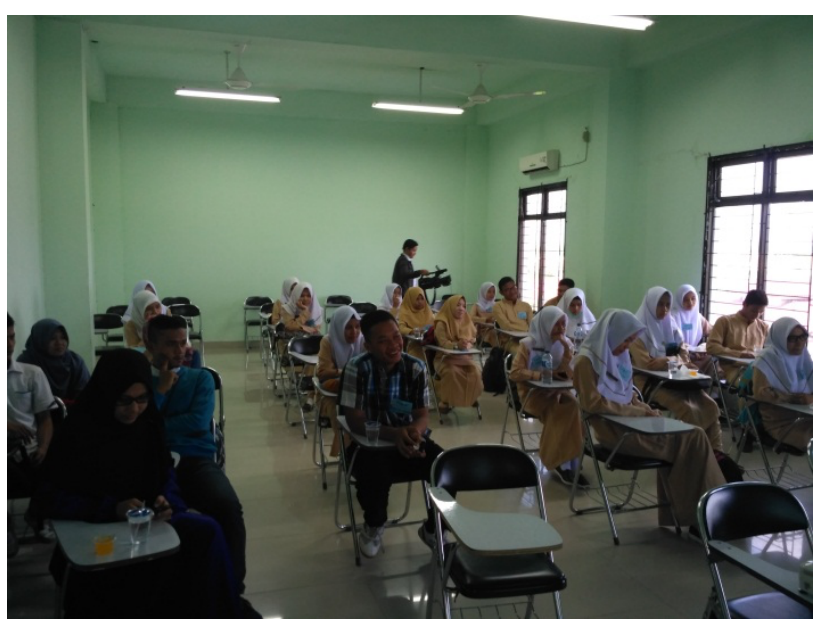

Gambar 5: Peserta Pelatihan

\section{KESIMPULAN}

Calon tenaga medis primer yang berasal dari Fakultas Ilmu kesehatan dan Ilmu Kedokteran Universitas Abdurrab yang mendapatkan materi tentang program pendampingan komunikasi kesehatan ini secara keseluruhan memiliki pengetahuan tentang komunikasi kesehatan (komkes) yang baik namun berdasarkan analis terhadap implementasi kom kes masih terdapat beberapa hal yang harus lebih ditingkatkan. Hal tersebut diantaranya adalah masih ragu memulai komunikasi dengan pasien, kurang komunikatif ketika berbicara di telphone dan bahkan sebagian ada yang mengabaikan telphone masuk karena manajemen tugas yang kurang baik pada saat bertugas dalam satu desk dengan rekan lainnya. 


\section{DAFTAR PUSTAKA}

Berry, Dianne. Health Communication Theory and Practice, open university press

Salisah, Nikmah Hadiati, 2011. Komunikasi Kesehatan: Perlunya Multidisipliner Dalam Ilmu Komunikasi, Jurnal Ilmu Komunikasi UIN, Surabaya.

http://www.cancer.gov/about-cancer/treatment/cam

http://nasional.republika.co.id/berita/nasional/daerah/15/09/16/nurjdx351-komunikasipenting-bagi-sektor-kesehatan-di-indonesia 